A N NALES

UNIVERSITATIS MARIAE CURIE-SKŁODOWSKA

LUBLIN - POLONIA

VOL. XXXV

SECTIO FF

$1-2017$

\title{
MICHAŁ ZDUNIK
}

Uniwersytet Warszawski

\section{(Auto)kreacje pamięci. Kilka uwag o Matka odchodzi Tadeusza Różewicza}

(Auto)creation of Memory. Few Remarks on Mother Departs by Tadeusz Różewicz

\section{UWAGI WSTĘPNE}

Zbiór Matka odchodzi został wydany w roku 1999 i spotykał się z entuzjastycznym przyjęciem - krytyka odczytuje go jako przejmujące, niemalże intymne pożegnanie poety z własną matką, rodzaj współczesnego trenu i traktuje jako jedno z największych osiągnięć poety (Drzewucki, 1999; Zaworska, 1999; Gębala, 2000; za: Skrendo, 2002:119-120). Powszechne uznanie dla tej książki było oczywiście słuszne ${ }^{1}$, choć można odnieść wrażenie, że zbyt szybko - i łatwo wpisano ją w przejrzyste gatunkowo ramy ,zapisanego wspomnienia”, a także wzięto za pewnik istnienie jednoznacznego i niezbywalnego na przestrzeni całego tekstu ,paktu autobiograficznego" (wedle terminologii Philippe'a Lejeune'a) (Lejeune, 2007:36). Wedle takiego założenia podstawowym, projektowanym

${ }^{1}$ Terminu „książka”, brzmiącego nieco potocznie, użyto z pełną odpowiedzialnością, aby celowo nie uruchamiać teoretycznoliterackich asocjacji, ale odnosić się do „przedmiotu materialnego w postaci zszywanych kartek tworzących wolumen, zawierający tekst słowny utrwalony w znakach graficznych i służący przekazywaniu i rozpowszechnianiu wszelkiego typu powiadomień" (Głowiński, Kostkiewiczowa, Okopień-Sławińska, Sławiński, 1988:43). Taka definicja, poprzez opis jedynie fizykalnego aspektu rzeczy, zachowuje neutralność oraz jest wolna od powierzchownych i zbyt pospiesznych interpretacji, ucieka od jednoznaczności - „książka” jako przedmiot nie niesie za sobą jeszcze żadnych znaczeń poza swoją materialnością. W przypadku utworów tak formalnie autonomicznych jak ten, wymykających się wszystkim genologicznym klasyfikacjom - jest to jedyne słuszne określenie, przynajmniej do momentu przeprowadzenia dokładnej analizy, która - być może - przybliży do dokładniejszego określenia gatunku tych utworów. 
celem podmiotu/autora tego dzieła byłoby przede wszystkim jak najdokładniejsze, niemalże dokumentalne przedstawienie historii matki i doświadczeń z nią związanych. Zakładałoby to, że Różewicz/podmiot mówiący powinien dążyć - przynajmniej intencjonalnie - do jak największej obiektywności w doborze, opracowaniu źródeł oraz ich opisaniu. Tymczasem - co postaram się wykazać w moim artykule - dzieje się wręcz przeciwnie; Różewicz celowo zaciemnia, stawia pytania, a nie daje odpowiedzi: źródła prezentuje bez komentarza; przepisuje wiersze, znacząco je modyfikując; ze spójnych dotychczas tekstów tworzy całostki jakby pęknięte, fragmentaryczne. Ta książka rządzi się bowiem inną narracją niż racjonalny tok dokumentarnej rekonstrukcji - zasadą subiektywnego i niedostępnego zewnętrznemu czytelnikowi mechanizmu indywidualnego wspominania. Jest to jednak projekt celowo niespójny i nigdy niedokończony - przeszłość bowiem okazuje się zawsze nieuchwytna, niemożliwa do całościowego opisania.

\section{BUDOWA FORMALNA - PIERWSZE ROZPOZNANIA}

Matka odchodzi Tadeusza Różewicza jest dziełem, pod względem gatunkowym i formalnym, wyjątkowo niejednorodnym. Składają się bowiem na nie przypomnijmy - wspomnienia (pisane w różnych okresach twórczości poety), fotografie, przedruki wierszy i prozy oraz fragmenty dziennika. Całość przypomina palimpsest albo, jak sugerował Robert Cieślak (2013:247), collage zbudowany na zasadzie powtórzenia, fragmentaryczności, wpisywania utworów literackich i wizualnych w nowy kontekst. Przyjrzymy się pierwszym tekstom/artefaktom/materiałom z książki.

Na stronie tytułowej zamieszczona jest fotografia starszej kobiety z podpisem „Oczy matki spoglądają na mnie” (Różewicz, 2004:5). Jako czytelnicy możemy tylko domyślać się, że zdjęcie przedstawia matkę poety - nigdzie nie powiedziano tego otwarcie. Co więcej, fotografia nie jest w żaden inny sposób opisana, brakuje daty, autora, pochodzenia, a także zaznaczenia obecności fotografii albo ilustracji w spisie treści. Ten fakt odnotował i zinterpretował Andrzej Skrendo:

W tomie [...] znajdujemy reprodukcje dokumentów - autentyczne zdjęcia, fotokopie listów oraz widokówki. [...] Jaką funkcję pełnią zebrane dokumenty? [...] Otrzymujemy sugestię, że następujące dalej teksty nie mają charakteru fikcyjnego, lecz są autentyczne, ponadto posiadają wartość sentymentalną, tworzą mianowicie zbiór pamiątek. [...] Na ogół zdjęcia mają zatem podtrzymywać sugestię, że książka Matka odchodzi to dokument (Skrendo, 2002:122-123).

Na ile jednak za autentyczne uznać możemy dokumenty, które nie spełniają podstawowych nawet cech dokumentarności? Skoro (jeśli pójść za wspominaną w poprzednim zdaniu intuicją Skrendy) traktowane są tak, jakby nie istniały 
(tj. nie ma ich w żadnym ze spisów), to właściwie w tym dziele są może nie tyle niepotrzebne, ile niekonieczne do jego zaistnienia i poprawnego odbioru. Ta wątpliwość - pojawiająca się już na samym początku lektury - każe zadać pytanie o autorski i podmiotowy status umieszczonych/reinterpretowanych tekstów kultury w zbiorze.

Po fotografii umieszczono fragment wspomnieniowej prozy Tadeusza Różewicza zatytułowany Teraz. Tekst nie pojawił się tutaj po raz pierwszy - przedtem został opublikowany, w nieco innej postaci, w „Twórczości” (Różewicz, 1999). Ten fakt, którym zajmę się nieco później, warto odnotować - nie jest to bowiem jedyny utwór, mający wcześniejszą wersję, a w Matka odchodzi został powtórzony (por. Skrendo, 2002). Czytamy w analizie Dariusza Szczukowskiego (2008:70) „Zbiór ten uderza swą różnorodnością, jest palimpsestem, w którym splatają się różne techniki i formy wypowiedzi. Zgodnie z poetyką powtórzenia został skonstruowany z wcześniej wydanych wierszy, umieszczonych w nowych konstelacjach"2. Innymi słowy, Matka odchodzi nie jest oryginalnie konstruowaną narracją, czyli taką, której elementy funkcjonowałyby tylko w jej kontekście i tworzyły logicznie następujące po sobie (gdyż tak zostały ułożone i zbudowane w autorskim zamyśle) ogniwa fabularnego napięcia i przebiegu. Oczywiście to, że tej książki nie można czytać jako linearnie zbudowanej całości. Można - wtedy okaże się, że Różewiczowi udało się nadać „,powtórzonym” elementom spójny kontekst i ułożyć widoczny ciąg następstw. Trzeba jednak zawsze pamiętać, że lektura będzie przebiegać dwoma niezależnymi od siebie torami - pierwszym, związanym z kontekstem pierwotnym danego tekstu i drugim, w którym ten sam fragment stanowi kolejną z części narracyjnie zamkniętej całości, jakim jest ów nowy, autonomiczny zbiór.

Poza próbą rekonstrukcji zamysłu, jaki przyświecał ułożeniu utworu w opisanej konfiguracji, trzeba więc będzie odpowiedzieć na kilka pytań, które się teraz pojawiły. Dlaczego Różewicz buduje narrację dającą się odczytywać (nie oceniając, czy błędnie, czy słusznie) jako niefikcjonalną prozę wspomnieniową, w sposób fragmentaryczny, palimpsestowy (zob. Genette, 1992); w którym zwraca uwagę na to, że dana cząstka całości może być czytana jako autonomiczna, samowystarczalna literacka jednostka, wraz ze swoim (tutaj wyrwanym) kontekstem? Przecież zgodnie z założeniami autobiografii (przyjęcie takiej ramy gatunkowej było wstępną hipotezą i punktem wyjścia do dyskusji) powinna być: ,retrospektywną opowieścią prozą, gdzie rzeczywista osoba przedstawia swoje życie, akcentując swoje jednostkowe losy, a zwłaszcza dzieje swej osobowości" (Lejeune, 2007:22). Lejeune (2007:22-23) w swojej - klasycznej już dzisiaj - definicji wyróżnia dwa warunki sine qua non autobiografii: tożsamość autora (któ-

${ }^{2} \mathrm{O}$ kategorii powtórzenia jako charakterystycznej dla formuł autobiograficznych zob. artykuł Marcina Wołka (2014). 
rego nazwisko odsyła do rzeczywistej osoby) z narratorem i tożsamość autora z głównym bohaterem. Nie możemy jednoznacznie stwierdzić, czy książka Różewicza spełnia pierwszy i drugi warunek, czy należy tu rozpatrywać każdy utwór pojedynczo, poddawać weryfikacji według postawionych reguł, czy może trzeba uznać, że pakt autobiograficzny (by pójść za metodologią francuskiego badacza), zawierany w książce kilkakrotnie, unieważnia pozostałe, fikcjonalne statusy wierszy lub prozy ${ }^{3}$. A może nie tyle unieważnia fikcjonalność tamtych utworów, ile dyskutuje z nimi, staje wobec nich, ukazuje rysy i pęknięcia na pozornie przejrzystej strukturze osobistego wspomnienia? Trochę mniej wątpliwości budzi drugi warunek - jeśli oczywiście przyjmiemy, co wydaje się chyba niewymagającym większego thumaczenia rozwiązaniem, że bohaterem zbioru jest nie Stefania Różewicz, lecz Tadeusz - jego pamięć, przeżycia, prowadzony przezeń dyskurs o matce ${ }^{4}$ (co nie zmienia faktu, iż identyfikacja autor - główny bohater nie zawsze będzie mogła być spełniona). Powyższe rozważania, wywołane niejako przez pierwszy tekst znajdujący się w tomiku, ustanawiają kolejne z pytań, które należy zadać książce Różewicza i konkretnym jej elementom. Będą to więc kwestie konkretnego autora/nadawcy, autobiograficzności (zgodnie z przywołanymi kategoriami), a także autonomiczności/nieautonomiczności (tj. związanego z całą narracją prowadzoną w Matka odchodzi) kontekstu poszczególnych utworów.

\section{FIGURY AUTORA: PYTANA BADAWCZE}

Wspomniany wcześniej tekst Teraz daje odpowiedzi na postawione pytania. Spełnione są warunki konieczne do zaistnienia paktu autobiograficznego (zgodnie z drugą odmianą pośredniego paktu autobiograficznego): narrator kilkakrotnie odnosi się do utworów Tadeusza Różewicza jako do własnych (Ojciec, Opowiadania o starych kobietach, Stara chtopka idzie brzegiem morza, $W$ środku życia; Różewicz, 2004:8-10) i do swojego (Różewicza) obiektywnie sprawdzalnego życiorysu. Autor jest więc tożsamy z narratorem, funkcjonuje jako główny bohater tego fragmentu. Umieszczenie szkicu na początku książki stanowi pewną ramę kompozycyjną i ideową - skoro otwierający tekst jest jawnie autobio-

${ }^{3}$ Pakt autobiograficzny Lejeune (2007:36) rozumie jako: „Pośrednio: a) użycie tytułu, który nie pozostawia wątpliwości, że pierwsza osoba odsyła do nazwiska autora; [...] b) w początkowej partii tekstu narrator formułuje swe zobowiązania wobec czytelnika, zachowując się tak, jakby był autorem i nie pozostawiając wątpliwości, że ja odsyła do nazwiska z okładki, choć nazwisko to nie pojawia się w tekście [i to ten rodzaj paktu autobiograficznego stosuje Różewicz - uzup. M.Z.] [...]. Bezpośrednio, kiedy w tekście narrator-bohater występuje pod takim samym nazwiskiem jak nazwisko autora na okładce".

${ }^{4}$ Pisał o tym German Ritz (2002:248): „Książka o matce nie jest jednak rodzinnym wspomnieniem, nie chodzi tu o los matki ani o nakreślenie jej portretu, co mógłby sugerować reprodukowany na okładce pamiątkowy medalion przedstawiający młodą kobietę - tematem jest tylko relacja między poetą a matką". 
graficzny (a także ustanawia perspektywę lektury poprzez kontekst Matki i jej spojrzenie) (Szczukowski, 2008:71), to czytelnik może się spodziewać, że podobny status będą miały pozostałe (a tym ciekawsze będą naruszenia tychże oczekiwań przez Różewicza). O tekście Teraz jako ramie kompozycyjnej pisze Skrendo (2002:128): Różewicz połączył bowiem trzy fragmenty, wydrukowane w „Twórczości" oddzielnie, w jeden utwór (Teraz), a czwarty z nich przesunął na koniec tomu (Do poprawki), tworząc tym samym formę otwieraną i zamykaną przez tę samą, powtarzaną formułę „Oczy matki spoglądają na mnie”. Z konstatacją Skrendy można się zgodzić - jednak późniejsze wnioski teoretyka są znacznie bardziej kontrowersyjne: traktuje on dwa ostatnie teksty w książce (autorstwa Janusza i Stanisława Różewiczów) jako aneks, a fragmenty wspomnień Matki jako wtrącenia, tym samym usuwając je poza główny poziom tekstu i stwierdzając, że są elementem dodatkowym, niekoniecznym do istnienia tej literackiej konstrukcji. Nie można uznać tej myśli, jak postaram się dalej udowodnić, za słuszną.

Następne utwory - znajdujące się wedle Skrendy poza dziełem - to dwa wspomnienia jego Matki: pierwsze oznaczone jedynie incipitem [Wieś mojego dzieciństwa], a drugie opatrzone tytułem Rok 1921, 9 października. Różewicz wspominał, że zostały spisane przez Matkę na jego prośbę, na krótko przed jej śmiercią (Drewnowski, 1990:62). To jednak wciąż niedokładna informacja-teksty pozbawione są datacji i dokładniejszych wskazań, dotyczących ich pochodzenia. Badacz zauważa, że nie jesteśmy w stanie w żaden sposób określić sytuacji narracyjnej, ustalić dystansu czasowego; zastanawia też fakt braku jakichkolwiek odniesień do życia prywatnego i zbliżającej się śmierci (Skrendo, 2002:128). Nie możemy również określić, jak dalekie były edytorskie ingerencje Różewicza - pomija on w książce uwagi na ten temat. To gest bardzo znaczący - o ile w przypadku wierszy i fragmentów prozy, mających wcześniejsze wersje, jesteśmy w stanie ustalić ich pierwotny kontekst (który Różewicz świadomie zaciera), o tyle tutaj stawia się odbiorcę w sytuacji niepewności czy wręcz braku zaufania wobec autora. Znaków świadczących o dokumentarności tych dwóch tekstów jest tak niewiele, że równie dobrze można zarówno uwierzyć podmiotowi umieszczającemu ten fragment w swoim dziele, jak i nie uznać autentyczności wspomnień. Jak tłumaczyć opisany gest? Odpowiedź na to pytanie - która pojawi się na końcu tekstu - będzie jednym z głównych wniosków sformułowanych przeze mnie po analizie Matka odchodzi.

\section{FIGURY AUTORA: SCHEMAT I STRUKTURA}

Wymienione wątpliwości sprawiają, że zaczynamy pojmować autorstwo tomiku jako konstrukcję wielopoziomową, w której elementy muszą koniecznie się 
uzupełniać. Można rozpisać ją w formie schematu ${ }^{5}$. Na jego najwyższym poziomie będzie funkcjonował:

A) autor (określony referencjalnie jako Tadeusz Różewicz z roku 1999 pierwodruku tomiku) książki Matka odchodzi. Będzie instancją najwyższą, bowiem odpowiada za wybór, układ tekstów względem siebie i ich ostateczny wygląd (skróty, zmiany itp.).

Na niższych poziomach struktury znajdują się kolejni autorzy:

a) Tadeuszowie Różewiczowie (przepraszam za tę niezręczną językowo formę) jako twórcy poszczególnych elementów (wierszy i fragmentów prozy), nieobarczonych jednoznacznie paktem autobiograficznym (Tadeusz Różewicz jest w pierwotnym założeniu innym podmiotem niż narrator/ nadawca);

b) Tadeuszowie Różewiczowie jako twórcy tekstów, które można uznać za autobiograficzne, niefikcjonalne (autor $=$ narrator $=$ bohater);

c) inni autorzy (niż a i b), których teksty znajdują się w książce, a dostęp do nich jest w praktyce możliwy tylko przez Tadeusza Różewicza; nie mogą autoryzować tekstów, funkcjonują poza nimi (Stefania i Janusz Różewiczowie);

d) autor A przepisujący w nowy kontekst teksty autorów c, a nawet z powodu braku odniesień tamtych fragmentów do ich oryginałów (dostęp do nich ma jedynie autor A, jednak w ogóle ich nie udostępnia, nie zaznacza nawet, gdzie mamy ich szukać) ustanawiający je na nowo, przez ich powtórny (a może dopiero pierwszy) publiczny zapis. Tym samym staje się ich współautorem;

e) inni (niż a, b i c) autorzy tekstów w książce; dostęp do oryginałów tych fragmentów jest w praktyce możliwy, jesteśmy pewni, że twórca autoryzował tekst w formie, w jakiej został tu opublikowany i że jest ona zgodna z jego zamysłem; funkcjonuje w tekście, jako jego jedyny autor (Stanisław Różewicz);

${ }^{5}$ Relacje autorskich podmiotów można również opracować na podstawie klasycznych już dzisiaj rozróżnień Aleksandry Okopień-Sławińskiej (zob. Okopień-Sławińska, 1985:84-99). Przedstawione klasyfikacje w dużej mierze opierają się na rozpoznaniach badaczki, wyróżniającej konkretne nadawcze i odbiorcze instancje w zewnątrztekstowym i wewnątrztekstowym poziomie komunikacji (zob. Okopień-Sławińska, 1985:98). 
f) inni (niż a, b i c) właściciele-autorzy fotografii i pocztówek ${ }^{6}$, mających status dokumentu (zdjęcia przedstawiające Matkę i Ojca Tadeusza oraz Janusza Różewicza i/lub do nich należące);

g) autor A wpisujący fotografie, pocztówki z podpunktu $\mathrm{f} i$ ich fakt przynależności w nowy kontekst, a ponadto powołujący do życia, ustanawiający je jako fragment dzieła, wydobywający z przestrzeni dokumentu, a także komentujący je;

h) Tadeusz Różewicz jako autor fragmentów autobiograficznej, intymnej, niefikcjonalnej prozy i osobistych dokumentów, których fragmenty znalazły się w książce (i które nie są powtórzeniem poprzedniego przepisania, np. w innym dziele);

i) autor A przepisujący dziennik, dokonujący wyboru fragmentów, zmieniający jego status z intymnego na publiczny, wpisujący w nowy kontekst;

j) autor A przepisujący niektóre $\mathrm{z}$ dokumentów z podpunktu h tylko częściowo - pozostawiający jednak ich pierwotną formę (rękopiśmienny zapis) i częściowo kontekst (bez komentarza można rozpoznać, z jakim gatunkiem, np. listem czy kalendarzykiem, mamy do czynienia), ale umieszczający je w nowej konfiguracji i dodający komentarz.

\section{FIGURY AUTORA: STRUKTURA A TEKSTY}

Spróbujmy wpisać w te kategorie określone utwory, aby zobaczyć, która $\mathrm{z}$ wymienionych grup jest $\mathrm{w}$ dziele Różewicza najsilniej reprezentowana, a także, by ustalić, jakie oddziałują między nimi napięcia - czy poszczególni „autorzy” dopełniają się, czy raczej zwalczają:

a) Ręce w kajdanach, dwa wyroki, Martwy owoc, Kasztan, Ściana, Powrót, Kopiec, Zabawa w konie, Ale kto zobaczy, Kobieta w czerni stapa po różach, Zły syn, Łza, Powrót do lasu, Domek, *** (Asyż gniazdo),

${ }^{6}$ Rzecz jasna nie uważam, że w przypadku nośnika, jakim jest fotografia, jej temat (osoba, która została uchwycona) jest równorzędny $\mathrm{z}$ autorem. W tym wypadku jednak jest nieco inaczej: autor pozostaje anonimowy, nigdy nie był zaznaczany, a celem fotografii nie jest realizacja jego intencji, a obrazowanie konkretnego podmiotu. Skoro więc pozycja autora zostaje niemalże całkowicie zniesiona, to jedynym podmiotem, który istnieje, w kontekście tejże fotografii, jest właśnie przedstawiana osoba (zawłaszczająca sobie tym samym pozycję autora albo transformująca ją na status właściciela fotografii). Taki sam proces zachodzi w przypadku zdjęć (np. pocztówek) nieprzedstawiających tych postaci, ale inny obiekt/podmiot/miejsce. Wtedy nie ma już znaczenia fakt rzeczywistej referencjalności do fotografowanego (nie jest ona zupełnie ważna, można by ją pominąc w tym układzie) i obecność fotografującego, a jedynie posiadanie przez daną osobę tego obrazu i obecność „faktu posiadania tego obrazu przez daną osobę” w pamięci innych. Ta przynależność przedmiotu-zdjęcia do danej osoby i pamięć tej przynależności znosi (i niejako zawłaszcza) anonimowe, praktycznie nieobecne i pozbawione znaczenia pozycje autora zdjęcia i przedstawianego, stając się tym samym jedyną semantyczną asocjacją związaną z obiektem (fotografią). 
*** (O świcie światto), Drzwi, Cierń, Złote góry, *** (Przedzierałem się przez ten sen), Ojciec, Tarcza z pajęczyny, Grzech;

b) Teraz, Wspomnienie z roku 1929, Odwiedziny dziadka, dwie siekierki, Łódź, Fotografia, *** (krzyknątem na nia), Czerwone pieczęcie, Matki boskiej gromnicznej, Po dwudziestu latach, Do poprawki;

$\mathrm{c} \rightarrow \mathrm{d})^{7}$ Stefania Różewicz: [Wieś mojego dzieciństwa], Rok 1921, 9 października; Janusz Różewicz: Droga ze szkoty do domu [fragment listu];

e) Stanisław Różewicz: $W$ kalejdoskopie;

$\mathrm{f} \rightarrow \mathrm{g}$ ) fotografia - portret matki (podpis: „Oczy matki spoczywają na mnie”), fotografia matki w stroju ludowym (podpis: „Mama po skończeniu kursów gospodarstwa domowego we dworze Państwa Kozarskich w Konopnicy”), wspólne zdjęcie matki i ojca (podpis: „Rodzice wybierają się z wizytą, mnie jeszcze wtedy nie było na świecie"), wspólne zdjęcie matki i Tadeusza Różewicza (podpis: „W kwietniu 1944 wyszedłem z lasu na przepustkę. Mama się ucieszyła...”), pocztówka (podpis: „Kartka z tajemniczej Erbalungi, małej miejscowości na północnym krańcu Korsyki”), zdjęcia matki (podpis: „Mama w stroju wizytowym”) i ojca (podpis: „Ojciec w stroju wizytowym. Tak się wtedy pozowało do zdjęć”), zdjęcia Janusza (podpis: „Janusz, starszy brat, po maturze") i jego dziewczyny z matką braci Różewiczów (podpis: „Mama z Zulką, dziewczyną Janusza”), zdjęcie Stanisława Różewicza z matką i kolegami (podpis: „Na majówce z Mamą: (od lewej) Stasio, przyszły ksiądz Marian, kolega Stasia - Pulek Ciesielski”), fotografia rodzinna (podpis: „A oto rodzina: (od lewej): Ojciec, Staś, Mama, Tadzio, Panna Zosia P. i Janusz”), zniszczone zdjęcie Ojca (podpis: „Ojciec był kawalerem pełnym fantazji");

$\mathrm{h} \rightarrow$ i) Dziennik gliwicki, Kartka wydarta z dziennika;

j) fotokopie listów Tadeusza do Matki (podpis: „Zachowane fragmenty listu do Mamy, pisanego przed Bożym Narodzeniem 1943 roku. Byłem wtedy w lesie"), fotokopia kartki z kalendarzyka (15-20 lipiec 1975, podpis: „Mój kalendarzyk na rok 1957 z notką o śmierci Mamy”).

\section{MATKA ODCHODZI JAKO GATUNEK JEDNORAZOWY}

To długie wyliczenie może przytłaczać, ale jest doskonałą ilustracją strategii Różewicza. Każdy utwór uruchamia bowiem nowy kontekst, przywołuje po-

${ }^{7}$ Znak „ $\rightarrow$ " - kategorie przechodzące i nakładające się na siebie, permanentnie zmieniające status, nieistniejące oddzielnie (jak przepisanie nie istnieje bez przepisywanego tekstu). 
przednie doświadczenie lekturowe, które jest utwierdzane albo unieważniane. Ale tu trzeba sobie zadać pytanie, czy ta przyjęta przez Różewicza forma ma rzeczywiście siłę, która może zmienić status dyskursu z fikcjonalnego na autobiograficzny. Gdyby tak było, okazałoby się, że musimy przeformułować swoje poprzednie recepcje wybranych utworów o charakterze niefikcjonalnym (które są - jak zauważyliśmy - w większości fałszywe); Różewicz znacznie zawęża pole ich interpretacji, każąc czytać je jako zapis autentycznego doświadczenia.

Można chyba zgodnie ustalić, że w Matka odchodzi nie mamy do czynienia $\mathrm{z}$ dokumentem, a jedynie (w tym wypadku) fałszywą stylizacją na taki dyskurs. „W zbiorze tym zastanawia przede wszystkim stylizacja na dyskurs dokumentalny, mająca postawić czytelnika przed prywatnym, głęboko intymnym, autobiograficznym doświadczeniem Różewicza” - pisze Szczukowski (2008:69-70). Rzeczywiście argumentów świadczących przeciw dokumentalności książki jest sporo: od wymienianych już przeze mnie braku dowodów autentyczności przytaczanych przedmiotów, przez fakt ich „przepisywania” bez możliwości weryfikacji zgodności z oryginałem, aż do niestabilnego statusu autora (czy może autorów) i zwalczających się charakterów poszczególnych fragmentów. Niestabilna jest więc również forma - oparta przecież głównie nie na oryginalnie stworzonej, spójnej wspomnieniowej narracji, ale na powtórzeniu, wrzuceniu pierwotnego tekstu w nowy, większy (nad)tekst. Skrendo zaznacza (2002:149):

Przychodzi uznać, iż otrzymaliśmy układ tekstów, które w sposób niejednoznaczny, często tylko pośredni, a w istocie niemożliwy do takiej rekonstrukcji, która pozwalałaby traktować cały tom jako dokument, odnoszący się do rzeczywistej postaci matki autora.

Dalej teoretyk stwierdza, że niemożliwe będzie „przedarcie się przez literackość" do postaci matki i prawdy o niej, gdyż ta prawda w ogóle nie istnieje, a wiedza o Matce jest fragmentaryczna.

Jednak dlaczego Różewicz zastosował właśnie taki sposób konstrukcji swojej książki - oparty na powtórzeniu, „udający” dokument (a więc, aby wyjaśnić poprzednią wątpliwość - nie może tu być mowy o zmianie statusu utworów autobiograficznych, gdyż stojąca u podstaw całości niefikcjonalność jest niejednoznaczna), w którym teksty zostały wielokrotnie przepisane i niekiedy, z powodu braku pierwotnych wersji, musimy stwierdzić, że autorów było właściwie wielu (tj. oryginalny i przepisujący) - i w umieszczonym w książce tekście nie sposób ich rozdzielić. Możemy więc wysnuć przypuszczenie, że celem nie jest obiektywne (a przynajmniej dążące do takiego) zapisywanie przeszłości (w sensie linearnej rekonstrukcji), a jej tworzenie przez przepisywanie dawnych fragmentów dobieranych czasami nie na zasadzie faktograficznej pewności, ale zwykłych skojarzeń autora. „Przeszłość” nie będzie więc prawidłowym określeniem. Traf- 
niejszym wydaje się „pamięć” i „wspomniane”. Jednak powiedzieć, że rozbita i fragmentaryczna forma stanowi po prostu ilustrację pamięci Różewicza, to stanowczo za mało, chociaż jest znaczącym przybliżeniem do istoty tej książki. Każe bowiem pojmować konstrukcję tomu jako całkowicie indywidualny wytwór autora $\mathrm{i}$ - mówiąc za Balcerzanem - gatunek jednorazowy.

Cóż mogłoby zagwarantować tekstowi poetyckiemu faktyczną niepowtarzalność? Niepowtarzalność dodajmy, pojmowaną dwojako: (1) autor danego liryku nie powtarza gotowych wzorców gatunkowych, i (2) nowy schemat komunikacyjny, stworzony w danym liryku, jest nie do powtórzenia w jakiejkolwiek innej, kolejnej realizacji poetyckiej (Balcerzan, 2006:160).

\section{NADRZĘDNĄ INSTANCJA AUTORSKA}

Jeśli rozszerzymy Balcerzanowską definicję nie tylko na liryki, ale także na większe formy i gatunki literackie, widzimy, że dwa te warunki zostają spełnione. Różewicz nie powtarza wzorców gatunkowych (być może w ogóle - jeśli chodzi o całą książkę - takich nie ma), ale korzysta z wielu schematów, które przekształca i zestawia ze sobą w nieoczekiwanych konfiguracjach, modyfikując niekiedy znacząco instancje nadawcze i formuły autobiograficzne. Jest więc to jeden z elementów świadczących o niepowtarzalności tego schematu komunikacyjnego, niemożliwy do powtórzenia także dlatego, że status dzieła Matka odchodzi uznać wypada za wyjątkowo niestabilny i niejednoznaczny. Autor tworzy tylko pozory dokumentalności, ale z drugiej strony nie możemy powiedzieć, aby jego dzieło było zupełnie fikcjonalne. Konstrukcja, jaką zaproponował, ma cechy literackie - oparta została na poetyce powtórzenia i fragmentu, ale przekracza granice literackości, daje w niektórych momentach dostęp do (niepewnej) prawdy o Matce i autentycznych przeżyć. Jest to więc sytuacja, w której nie sposób rozdzielić dwóch charakterów - autobiograficznego i fikcjonalnego (którymi pierwotnie naznaczono wiele utworów w książce), ponieważ pamięć, wedle Różewicza, może być reprezentowana przez język tylko wtedy, kiedy jest formą literacką (i narzucającą pewną fikcjonalność), zaś wiersze czy fragmenty prozy niebędące pierwotnie osobistymi wspomnieniami autora dają się w niektórych kontekstach odczytać jako zapis autentycznych przeżyć. Matka odchodzi jest i nie jest dokumentem, tak samo jak jest i nie jest fikcjonalną literaturą, ale te wzajemne negacje nie są linearnym procesem, a przenikającymi się sposobami istnienia komunikatu.

Zatem jedyny podmiot zdolny do zweryfikowania autentyczności dzieła to sam autor; czytelnik nie może stwierdzić, co tu jest literackie, a co nieliterackie, co autentyczne, a co fikcyjne, gdyż podmiot organizujący utwór zespala kategorie, neguje je, odbiera jednoznaczny klucz interpretacyjny. I być może tylko $\mathrm{w}$ tym sensie ten jednorazowy gatunek jest intymny; jego jednoznaczne wyjaśnienie i stabilność należą do podmiotu organizującego - Tadeusza Różewicza (od- 
biorca nie zostaje w żaden sposób do osobistej przestrzeni autora bliżej dopuszczony!). Tylko on ma dostęp do oryginału i przepisuje teksty, swobodnie zmienia ich status, podaje je do druku i wtłacza w nową narrację, stając się dla poprzedniego podmiotu je piszącego równorzędnym - a nawet nadrzędnym (jako jedyny ma siłę te teksty organizującą). Nadaje im arbitralnie charakter obiektywnego dokumentu, a z powodu braku sprawdzalności wobec pierwowzoru, czytelnik musi uwierzyć, że Różewicz przepisuje, a nie pisze obce (tj. Janusza i Stefanii Różewiczów) teksty. Co więcej, jest jedynym autorem nowego gatunku i jako jedyny może rozłożyć go na czynniki pierwsze, znaleźć odpowiedzi na pytania dotyczące odtworzonego i tworzonego.

Mówiąc o kwestiach gatunkowych, warto wspomnieć jeszcze o kategorii „sylw współczesnych”, wprowadzonej przez Ryszarda Nycza, która prawdopodobnie byłaby najtrafniejszym pojęciem opisu tomu Matka odchodzi Tadeusza Różewicza. Jak pamiętamy, mianem sylw współczesnych określano teksty (polskiej literatury XX-wiecznej) celowo niespójne, o brulionowym charakterze, działające na zasadzie metatekstowej (aluzyjnej i cytatowej), posiadające niestabilny, wielogłosowy podmiot, często odwołujący się do doświadczeń autobiograficznych (zob. Nycz, 1996:13-50). Fragmentaryczna, ,powtórzeniowa” i autofikcjonalna konstrukcja tekstu Rożewicza sprawia, że można go interpretować również jako sylwę współczesną.

\section{PODSUMOWANIE I DALSZE PYTANIA BADAWCZE}

Matka odchodzi jest dziełem, które wykracza poza konwencjonalny gatunek autobiograficzny (wedle wyznacznika Lejeune'a), a staje się raczej ponowoczesnym palimpsestem, w którym teksty poddane są znaczącej rekontekstualizacji (modyfikuje się pozycję autentycznego, autorskiego/fikcjonalnego nadawcy), a tym samym zaczynają funkcjonować dychotomicznie (jak utwór autonomiczny i część nowej całości). Różnorodność podmiotów nadawczych sprawia, że lektura książki jako spójnego zapisu osobistego dokumentu/wspomnienia staje się wręcz niemożliwa. Różewicz tworzy specyficzny gatunek jednorazowy, którego autentyczności nie sposób zweryfikować (z powodu obecności różnych „autorów”). Dostęp do jego wewnętrznego porządku i konstrukcyjnych reguł ma bowiem tylko poeta, arbitralnie nadający tekstom nowe, niefikcjonalne statusy; ma dostęp do oryginałów, układa je w różnorodne, niespotykane, konstelacje. Książka Matka odchodzi została skonstruowana jako permanentna (auto)kreacja pamięci - oparta na tworzeniu kontekstów, zmianie statusów fikcjonalności czy publikacji dostępnych tylko autorowi materiałów - i może dlatego jest formułą tak bardzo niespójną, palimpsestową i polifoniczną, przypominającą pozbawiony stabilności zapis procesu rekonstruowania przeszłości (z pokazaniem jego technicznej strony). 
Rzecz jasna nie odpowiedziałem na wszystkie pytania, przed jakimi staje czytelnik tomu Różewicza, należałoby jeszcze przeanalizować funkcję zamieszczonych w nim fotografii (przy czym, co zaznaczał Szczukowski, pomocne byłyby tu klasyczne dzisiaj rozpoznania Rolanda Barthesa i Susan Sontag) (Szczukowski, 2008; Barthes, 2008; Sontag, 2009) i fotokopii dokumentów osobistych ${ }^{8}$, dokonać stylistycznej lektury tekstów oraz analizy porównawczej różnych wersji wierszy czy wreszcie omówić kwestię projektowanej uniwersalności/intymności zbioru (np. możliwość teatralnej inscenizacji). Zagadnienia te warto by podjąć w kolejnym tekście, omawiającym inne aspekty książki Różewicza.

\section{BIBLIOGRAFIA}

Balcerzan, Edward. (2006). Przez znaki. Granice autonomii sztuki poetyckiej na materiale polskiej poezji współczesnej. Gdańsk: Tower Press.

Barthes, Roland. (2008). Światło obrazu. Uwagi o fotografii. Tłum. Jacek Trznadel. Warszawa: Aletheia.

Cieślak, Robert. (2013). Widzenie Różewicza. Warszawa: Wydawnictwa Uniwersytetu Warszawskiego.

Drewnowski, Tadeusz. (1990). Walka o oddech. Warszawa: Wydawnictwa Artystyczne i Filmowe.

Drzewucki, Janusz. (1999). Matka poety i poeta. Rzeczpospolita, 255, s. 4.

Gębala, Stanisław. (2000). Oczy matki i suche oczy poety. Twórczość, 4, s. 98-101.

Genette, Gérard. (1996). Palimpsesty. Literatura drugiego stopnia. W: Henryk Markiewicz (red.). Wspótczesna teoria badań literackich za granica. Antologia. T. 4, cz. 2. Przeł. Aleksander Milecki. Kraków: Wydawnictwo Literackie.

Głowiński, Michał, Kostkiewiczowa, Teresa, Okopień-Sławińska, Aleksandra, Sławiński, Janusz (red.). (1988). Stownik terminów literackich. Wrocław: Ossolineum.

Kruszewski, Wojciech. (2010). Rękopisy i formy. Lublin: Wydawnictwo KUL.

Lejeune, Philippe. (2007). „Pakt autobiograficzny”. W: Regina Lubasz-Bartoszyńska (red.). Wariacje na temat pewnego paktu. O autobiografii (s. 21-56). Tłum. Aleksander Labuda. Kraków: Universitas.

Nycz, Ryszard. (1996). Sylwy współczesne. Kraków: Universitas.

Okopień-Sławińska, Aleksandra. (1985). Semantyka wypowiedzi poetyckiej (preliminaria). Wrocław: Ossolineum.

Ritz, German. (2002). „Tadeusz Różewicz: Matka odchodzi - początek lektury psychopoetyckiej”. W: Nić w labiryncie pożadania. Gender i pleć w literaturze polskiej od romantyzmu do postmodernizmu (s. 246-259). Tłum. Małgorzata Łukasiewicz. Warszawa: Wiedza Powszechna.

Różewicz, Tadeusz. (1988). Poezja 1-2. Kraków: Wydawnictwo Literackie.

Różewicz, Tadeusz. (1990). Proza 1-2. Kraków: Wydawnictwo Literackie.

Różewicz, Tadeusz. (2004). Matka odchodzi. Wrocław: Wydawnictwo Dolnośląskie.

Różewicz, Tadeusz. (2004a). Proza 4. Wrocław: Wydawnictwo Dolnośląskie.

Różewicz, Tadeusz. (1988). Teatr 1. Kraków: Wydawnictwo Literackie.

Różewicz, Tadeusz. (1985). Echa leśne. Warszawa: Państwowy Instytut Wydawniczy.

Różewicz, Tadeusz. (1999). Teraz. Twórczość, 10, s. 3-7.

${ }^{8}$ Znakomitą analizę relacji wizualnych w Matka odchodzi dokonuje Robert Cieślak w książce Widzenie Różewicza (2013:239-250). 
Skrendo, Andrzej. (2002). Tadeusz Różewicz i granice literatury. Poetyka i etyka transgresji. Kraków: Universitas.

Skrendo, Andrzej. (2000). Żebracze treny Tadeusza Różewicza. Kultura, 3, s. 146-152.

Sontag, Susan. (2009). O fotografii. Tłum. Sławomir Magala. Kraków: Karakter.

Szczukowski, Dariusz. (2008). Tadeusz Różewicz wobec niewyrażalnego. Kraków: Universitas.

Wołk, Marcin. (2014). Autobiografia i powtórzenie. Zagadnienia Rodzajów Literackich, 2, s. 87-98.

Zaworska, Helena. (1999). Treny Różewicza. Gazeta Wyborcza, 232, s. 14-15.

\section{STRESZCZENIE}

Tematem artykułu jest wspomnieniowy tom Matka odchodzi (1999) Tadeusza Różewicza - książka wyjątkowa, polifoniczna, palimpsestowa i niespójna. W pracy dokonano analizy obecnych w dziele podmiotów autorskich, a także zweryfikowano przeświadczenie o autobiograficzności tekstu (według terminologii Lejeuene'a). Lektura wykazała, iż w tomie Różewicza brak jednego, spójnego, równoznacznego z rzeczywistym autorem podmiotu mówiącego oraz że umieszczone w książce teksty mają często podwójny, zależny od kontekstu, status (fikcjonalny/niefikcjonalny). Uznano więc, że Różewicz tworzy swoisty „gatunek jednorazowy” (termin Balcerzana) - wyjątkowo intymny i nieprzejrzysty, będący zapisem jego procesu wspominania, a więc niejako (pod względem wglądu do jego konstrukcyjnych reguł) niedostępny zewnętrznemu czytelnikowi.

Slowa klucze: Tadeusz Różewicz, Matka odchodzi, autobiografizm, pakt autobiograficzny, palimpsest, pamięć, modernizm

\section{SUMMARY}

The main topic of this paper is a book entitled Mother Departs (1999) by Tadeusz Różewicz a kind of polyphonic palimpsest, a memoir (with narrative prose, poems, photographies, etc.). In this article, the author analyzes statuses of many "authors" and lyrical subjects in Różewicz's works and verifies a hypothesis about autobiographism of this book (in Lejeune's understanding). It is also shown that there is no one coherent subject (identical with the real author) and the texts are, at the same time, fictional and nonfictional. Therefore, it is regarded that Tadeusz Różewicz creates a kind of "unique genre" (a term by E. Balcerzan), which is a literary form of his memory processes. For this reason, its construction is unavailable for an external reader.

Keywords: Tadeusz Różewicz, Mother Departs, authobiographism, the autobiographical pact, palimpsest, memory, modernism 